\title{
The Impact of Supply Chain Integration and Trust on Supply Chain Performance: Evidence from Indonesia Retail Sector
}

\author{
Submitted 20/12/20, $1^{\text {st }}$ revision 28/01/21, $2^{\text {nd }}$ revision 09/02/21, accepted 20/03/21
}

\author{
J.E. Sutanto ${ }^{1}$, Arnold Japutra ${ }^{2}$
}

\begin{abstract}
:
Purpose: This study is to determine the impact of supply chain integration and trust on supply chain performance.

Design/Methodology/Approach: The research was conducted empirically on supply chain activities at Indomaret outlets in Indonesia and as a representative of outlets with a total sample of 145 outlets. Factor analysis and multiple linear regression using the SPSS program with version 25 for data analysis.

Findings: The finding of this study reveals that all variables of supply chain integration are supplier integration (SI), customer integration (CI), process integration (PI), and trust (TR), both partially and simultaneously are stated to have a significant effect on supply chain performance (SCP).

Practical Implications: Based on the results the suggestion is the company must integrate the internal processes and continue by integrating with external companies, namely supplier integration and customer integration or distributor.

Original/value: Find novelty of this study is implementing supply chain collaboration for development in the business retail sector, especially in Indonesia. Secondly, this study shows collaboration as a communication aspect like formal and informal contact.
\end{abstract}

Keyword: Supplier integration, Customer integration, Process integration, Supply chain performance, Retail.

JEL Classification: L81, D12, L17.

Paper Type: Research Paper.

Acknowledgment: We would like to say our gratitude to Prof. Dr. Ch. Whidya Utami, M.M, as the mentor in his research, as a scientist, and as the professor, has a pervasive insight and knowledge of the basics, which can be the necessary foundation for any author in his research. Thanks to the publisher, who has published the article in this journal.

\footnotetext{
${ }^{1}$ Universitas Ciputra Surabaya, East Java, Indonesia, je.sutanto@ciputra.ac.id

${ }^{2}$ The University of Western Australia, Perth-Australia, Arnold.japutra@uwa.edu.au
} 


\section{Introduction}

The problem that often occurs in companies that manage networked minimarkets is the lack of control over logistics management, logistic distribution policy. PT. Indomarco Prismata has been optimal in that the company can be more efficient and effective in logistic distribution performance, distribution center location, smoothness that occurs in logistics distribution management control will affect company performance (Bagher, 2018; Patel, 2017; Sezhiyan et al., 2011) in distributing requests to customer outlets and managing product inventory in distribution centers. PT. Indomarco Prismatama is a holding company that manages Indomaret outlets, including in cities/regencies throughout Indonesia. According to Ariani (2013), the industry needs an appropriate strategy to survive in the market and face competition, threats, and market opportunities. The company's supply chain performance is needed to survive in increasingly fierce market competition; through supply chain management, the company creates its competitive strategy to form the right image for consumers and suppliers, and parties involved in market share (Srinita, 2018). Currently, Indomaret is proliferating with the number of outlets reaching 16,000 outlets consisting of $40 \%$ franchise outlets and $60 \%$ company-owned outlets, the supply of all outlets consists of 33 distribution centers that provide more than 5000 types of products.

In this study, the object in the Indomaret outlet is owned by PT. Indomarco Prismatama, which is the largest franchise retail company in Indonesia. Indomaret outlets act as retailers in the supply chain related to consumers to meet consumer needs and demands in the market. Some of the problems that arise at Indomaret outlets are mainly problems in the supply of goods/products; often, the supply of these goods/products experiences delays in delivery which causes consumers to switch to outlets other than Indomaret. These problems pose a threat to market opportunities and reduce the company's competitiveness. Competition between companies in market share cannot be avoided because each company tries to meet market demand. For this reason, companies must have a strategy to improve supply chain management performance, so the effect for the company will be to survive in the competition (Zainurossalamia and Hidayati, 2020). The performance of the supply chain itself does not rule out being influenced by other factors because, in its implementation, there are processes that involve companies with formal and informal partners (Mols et al., 2012)

The company also considers supplier integration to increase the efficiency and effectiveness of information so that the transaction process between producers and suppliers can run smoothly and ultimately impact sustainable excellence (Lai et al., 2012; Zhao et al., 2013). Then, another factor is customer integration; in this cases supply chain is centered on collected information from customers regarding the repurchase model, consumer preferences for the product and ultimately used by the company as a basis for decision making towards customers (Lotfi et al., 2013) The existence of supplier integration as one that encourages customers, how to improve 
the experience of dealing with customers or serve customers better (Kumar et al., 2019). Flynn et al. (2010) stated that the influence between the firm performance to suppliers and customers integration on improving the performance of new products and business performance is positive. Process integrations integrate departments or organizations in a complex supply chain and can increase efficiency and effectiveness in the production process. Therefore, even though there is already an integrated supplier and customer integration running well, the process integration factor is supportive of supply chain integration.

There is a collaboration between organizations, so each organization must have each other and at the same time maintain trust both internally and externally because trust and collaboration in supply chain management (SCM) are the most effective and efficient solutions (Cao et al., 2014, Dominguez, et al., 2014; Sari, 2015; Nagashima et al., 2015).

\section{Literature Review}

To increase competitiveness among companies globally, it is necessary to implement strategies to partner with other companies that will affect competitive advantage (Huang et al., 2014). Several performance indicators of organizations need to improve, through supply chain integration and regulations, other globalization factors drive supply chain integration among firms (Goeltz, 2014; Hugos, 2011). Meanwhile, Huo et al. (2014) found companies with strong internal integration in business processes to improve financial performance. When the supply chain members are integrated, and there is a proper communication flow, the company can quickly adjust to any market changes, either in the long or short term (Seebacher and Winkler, 2015). The joint SCI partnership with a win-win situation helps the organization find the best way to reduce production, inventory, or transaction costs and increase profitability (Deshpande, 2012). Therefore, SCI brings many benefits to the organization. The company's performance to integrate it is internal or external with its supply chain partners supports its ability to respond to market demands (Kumar et al., 2017).

Integration also experiences barriers due to conflicting interests in the supply chain and other reasons. Different departments have different goals and objectives (Sambasivan et al., 2011), and because this information can be used to increase competitive advantage (AlSagheer and Ahli, 2011).

\subsection{Supply Chain Performance (SCP)}

The purpose of supply chain performance is to increase sales in the form of goods or services. Besides that, they are keeping expenses to a minimum. Logistics Management previously focused solely on procurement, shipping, maintenance, inventory management, and distributing. In essence, the supply chain increases value, such as new product development, marketing, finance, and production processes. The 
development of SCP has specific objectives such as customer need and sustainable firm performance (Hassan et al., 2015). The SCM performance is determined by various parameters such as measures for operations, organization, company, and finance. One of the models used to measure overall performance, resources are taken into consideration on costs, product quality, response, customer satisfaction, production capacity, schedule, lead time (Shahbaz et al., 2018). Thus, this study must consider everything that is required so that operational performance can be achieved. In this case, if only financial indicators are not relevant to measure all of the performance or accuracy. Therefore, using the balanced scorecard approach, operational indicators are needed (Attia, 2015; Shahbaz et al., 2018). Meanwhile, the production process and activities are associated with converting inputs into outputs (Linic et al., 2011; Boutayeba, 2017). The supply chain does not only occur in one direction but also emphasizes information flow and inventory management ( $\mathrm{Wu}$ et al., 2014)

One of the important indicators for testing the achievement of supplier performance is by using its performance. Research results related to the performance of suppliers, as suppliers who have sent products to buyers. (Zainurossalamia and Hidayati, 2020). With global competition, it is necessary to have the cooperation of all supplier members. Performance must be measured using supply chain performance if the supply chain organization is successful when it can keep business performance surviving, efficient, and effective (Basu et al., 2017).

\subsection{Supplier Integration (SI)}

Supplier integration is the existence of cooperation or partnership between companies and their suppliers. In this case, the activity is to make plans, develop interorganizational strategies, develop an integrated process for sharing information and experiences in running the organization (Flynn et al., 2010). In the company's internal supply chain, there is also a production process where products are produced based on the production process starting from raw materials to finished goods, provided that the raw materials are of high quality so that the finished goods are also of high quality (He et al., 2014).

Lamb et al. (2011) stated that SI is a continuous collaboration between companies with outside parties to provide services and supply goods so that the relationship that occurs is a form of providing a good customer experience for external parties. Supplier Integration prioritizes service to customers according to agreed terms and product specifications and responds to market changes (Zhao et al., 2013). According to Munch (2015), Supplier Integration becomes an organizational model in company integration as a whole and between departments from suppliers, shipping goods, manufacturers of finished goods to consumers (Wong et al., 2011).

According to Zhao et al. (2013), internal partners and external partners combine strategies, practices, and processes between organizations to collaborative processes. 
Also, it is synchronized, which involves the need for interrelated core competencies, especially with critical suppliers.

This study uses indicators maintaining cooperative relationships with suppliers, creating long-term relationships with suppliers, and involving suppliers to improve the quality of company services. Several studies have shown a higher level of supplier integration potential to more significant benefits (Alfalla et al., 2013; Huo, 2012; Moyano et al., 2016).

\subsection{Customer Integration (CI)}

According to Lamb et al. (2011), CI is a capability that allows companies to offer value-added offerings that are durable, distinctive, and valuable to customers that represent the most excellent value for the company or supply chain. Also, according to Chavez et al. (2015), Customer Integration, in general, is always related to collaborative activities such as frequent contact with customers. According to Zhao et al. (2013), producers collaborate in the form of partnerships, both internally and with external partners, every time they formulate strategies, practices, partners between organizations into a collaborative and synchronized process involving customers. This study uses indicators providing periodic information to customers, providing feedback from customers, responsiveness to customer needs, surveying customer needs. Customer integration in the supply chain can explain to the company that it has a framework for specific requirements and needs to serve consumers well.

To obtain information from customers, such as a purchase transaction, this event integrates customers, while consumer preferences for products and consumers' ability to buy products can be used in decision making (Lotfi et al., 2013). When companies collaborate with customers, it means good response, which is very efficient in achieving sales targets. There are several findings that customer integration is significantly correlated with supplier integration so that coordination between partners has a positive impact and ultimately affects the organization's performance (Lau et al., 2010).

\subsection{Process Integration (PI)}

Integration is the joining of parts or activities to form an entire system. Integration can improve relationships in each supply chain, facilitate decision making, value creation, and information from supplier to end-user, namely consumers. Integration in the supply chain shows a complicated collaborative relationship between parties in the supply chain, which, if appropriately managed, will increase efficiency and effectiveness in the production process to increase company profits and satisfy consumers (Ariani, 2013).

PI occurs when companies cooperate with suppliers to compile and prepare interdepartmental processes, including supplier involvement in product development, 
and company performance, so that performance between departments or organizations can better meet market demands and respond to market share (Schoenherr and Swink, 2012). As a basis for decision making, it can be done together and look for joint solutions in facilitating companies and suppliers to help avoid possible conflicts and serve customers better (Palomero and Chalmeta, 2014). The involvement of suppliers in product development, production planning, and project teams to improve business performance (Lai et al., 2012), and reduce production waiting times, accelerate the introduction and delivery of new products $(\mathrm{Yu}, 2015)$. To get a solution together with a supplier means increasing responsiveness to market demands and reducing operating costs (Huo, 2012). PI, with suppliers, can achieve operational synergy and a higher efficiency level, improving company performance.

Also, research by Ariani (2013), entitled analysis of the effect of supply chain management on company capability and study from Mellat-Parast and Spillan (2014) entitled logistics and supply chain process integration as a source of competitive advantage also states the same thing that the process integration has a positive effect on supply chain management performance.

\subsection{Trust (TR)}

Trust has defined to what extent a person has self-confidence and is willing to do it based on words, actions and uses the system in cross-departmental coordination. (Bunduchi, 2013). Trust arises from the ability and willingness to form the consistency of trust, willingness to do something, and expertise. Xiao et al. (2010) state that trust or trust is expected to trust business partners expected to be reliable in carrying out their duties.

Trust is essential in a collaborative relationship because it plays a vital role in building communication and cooperation in dealing with and solving problems that arise in a relationship (Zhang et al., 2018). Parties who have mutual trust in one partner company will have high integrity and quality. According to Bowersox (2013), to build trust, the first thing needed is to show that the company can be relied on in its operations and is consistent in showing the promised performance. Trust is an essential factor in building a supply chain management because trust will reduce the uncertainty (Majid, 2017), while, according to Almeidá et al. (2017), the principle of the company, giving priority to suppliers to end-users must both can make a profit, and the presence of quality products, relatively stable prices, affordable prices and credibility (Delbufalo, 2012). In these cases, trust is essential in building communication and cooperation because it can make relationships stable.

\subsection{Proposed Research Model}

The research model used in this study is shown in Figure 1. 
Figure 1. Research Model for retail sector in Indonesia

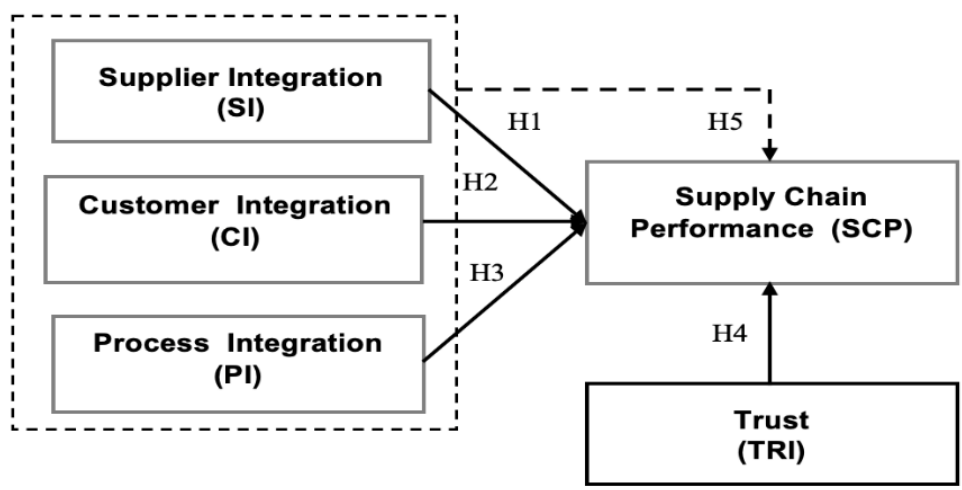

Source: Own creation.

The study examines the retail sector supply chain; Hence, the following hypothesis will be tested:

H1 : Supplier integration has a positive on supply chain performance

$\boldsymbol{H 2}$ : Customer integration has a positive on supply chain performance

$\boldsymbol{H 3}$ : Process integration has a positive on supply chain performance

H4 : Trust has positive on supply chain performance

H5 : Supplier integration, customer integration, process integration and trust, simultaneously has a positive on supply chain performance

\section{Research Methods}

Sampling as a respondent in the study was taken from several Infomart retailers in cities and districts in Indonesia, including Surabaya, Malang, Madiun, Sidoarjo, and Jember. While the total sample consisted of 145 respondents; and the criteria for the respondents were Supervisors with a minimum work experience of 2 years.

Validity and reliability tests were carried out before researching the number of samples that had been determined, namely 145 respondents. The validity test's purpose is to ensure that the research instrument to be used has been declared valid for all indicators (Sugiyono, 2017). Meanwhile, the aim of conducting a reliability test is to find out the consistency of the instrument if it is used at different times and places, and the instrument is said to be reliable if all indicators have the value of Cronbach's alpha > 0.6, with a Cronbach's value > Cronbach's alpha if deleted (Ghozali, 2018; Sugiyono, 2017).

\section{Result and Discussion}

To test the validity of the instrument using the SPSS version 25 program (Santoso, 2019). The results of the validity test are in Table 1. 


\section{a. Validity Testing}

The purpose and objective of validity testing is to test whether the instrument is valid or not before the research is used, so it must be ensured that the instrument is valid for all indicators Table 1).

Table 1. Result of Validity Test of Instrument

\begin{tabular}{|c|c|c|c|c|}
\hline Variables & $\begin{array}{c}\text { Indicator } \\
\mathrm{s}\end{array}$ & $\begin{array}{c}\text { Pearson } \\
\text { Correlation } \\
\end{array}$ & Sig. & Remarks \\
\hline \multirow{3}{*}{$\begin{array}{l}\text { Supplier } \\
\text { Integration }\end{array}$} & SI1 & 0.990 & 0.000 & \multirow{3}{*}{ valid } \\
\hline & SI2 & 0.960 & 0.000 & \\
\hline & SI3 & 0.990 & 0.000 & \\
\hline \multirow{3}{*}{$\begin{array}{l}\text { Customer } \\
\text { Integration }\end{array}$} & CI1 & 0.964 & 0.000 & \multirow{3}{*}{ valid } \\
\hline & CI2 & 0.939 & 0.000 & \\
\hline & $\mathrm{CI} 3$ & 0.988 & 0.000 & \\
\hline \multirow{3}{*}{$\begin{array}{c}\text { Process } \\
\text { Integration }\end{array}$} & PI1 & 0.989 & 0.000 & \multirow{3}{*}{ valid } \\
\hline & PI2 & 0.963 & 0.000 & \\
\hline & PI3 & 0.989 & 0.000 & \\
\hline \multirow{3}{*}{ Trust } & TR1 & 0.840 & 0.000 & \multirow{3}{*}{ valid } \\
\hline & TR2 & 0.730 & 0.000 & \\
\hline & TR3 & 0.798 & 0.000 & \\
\hline \multirow{4}{*}{$\begin{array}{l}\text { Supply Chain } \\
\text { Performance }\end{array}$} & SCP1 & 0.707 & 0.000 & \multirow{4}{*}{ valid } \\
\hline & SCP2 & 0.694 & 0.000 & \\
\hline & SCP3 & 0.711 & 0.000 & \\
\hline & SCP4 & 0.713 & 0.000 & \\
\hline
\end{tabular}

\section{Source: Own creation.}

\section{b. Reliability Testing}

The instrument is not only tested for validity, but also for reliability testing, the aim is to prove that the instrument has consistency, so that each indicator can be declared reliable see in Table 2.

Table 2. Result of Reliability Test of Instrument

\begin{tabular}{|c|c|c|c|c|}
\hline Variables & $\begin{array}{l}\text { Indicato } \\
\text { rs }\end{array}$ & $\begin{array}{c}\text { Cronbach's } \\
\text { Alpha If } \\
\text { Deleted }\end{array}$ & $\begin{array}{c}\text { Cronbach's } \\
\text { Alpha }\end{array}$ & $\begin{array}{c}\text { Remar } \\
\text { ks }\end{array}$ \\
\hline \multirow{3}{*}{ Supplier Integration } & SI1 & 0.833 & \multirow{3}{*}{0.884} & \multirow{3}{*}{ reliable } \\
\hline & SI2 & 0.842 & & \\
\hline & SI3 & 0.833 & & \\
\hline \multirow{3}{*}{$\begin{array}{l}\text { Customer } \\
\text { Integration }\end{array}$} & CI1 & 0.830 & \multirow{3}{*}{0.880} & \multirow{3}{*}{ reliable } \\
\hline & CI2 & 0.842 & & \\
\hline & $\mathrm{CI} 3$ & 0.827 & & \\
\hline \multirow{3}{*}{$\begin{array}{l}\text { Process } \\
\text { Integration }\end{array}$} & PI1 & 0.832 & \multirow{3}{*}{0.883} & \multirow{3}{*}{ reliable } \\
\hline & PI2 & 0.840 & & \\
\hline & PI3 & 0.832 & & \\
\hline
\end{tabular}




\begin{tabular}{|c|l|l|l|l|}
\multirow{4}{*}{ Trust } & TR1 & 0.805 & \multirow{2}{*}{0.848} & reliable \\
\cline { 2 - 3 } & TR2 & 0.811 & & \\
\cline { 2 - 3 } & TR3 & 0.790 & & \\
Supply Chain & SCP1 & 0.744 & & reliable \\
\cline { 2 - 3 } Performance & SCP2 & 0.750 & 0.781 & \\
\cline { 2 - 3 } & SCP3 & 0.745 & & \\
\cline { 2 - 3 } & SCP4 & 0.745 & & \\
\hline
\end{tabular}

Source: Own creation.

\subsection{Multiple Linear Regression Analysis}

Analysis of the regression model for supplier integration, customer integration, process integration, and trust is shown in Table 3.

Table 3. Analysis of The Regression Model for Supplier Integration, Customer Integration, Process Integration, and Trust

\begin{tabular}{|c|l|c|c|c|c|c|}
\hline \multicolumn{2}{|c|}{ Model } & \multicolumn{2}{|c|}{$\begin{array}{c}\text { Unstandardized } \\
\text { Coefficients }\end{array}$} & $\begin{array}{c}\text { Standardized } \\
\text { Coefficients }\end{array}$ & \multirow{2}{*}{ Sig. } & \\
\cline { 3 - 7 } \multicolumn{2}{c|}{} & B & $\begin{array}{c}\text { Std. } \\
\text { Error }\end{array}$ & Beta & & \\
\hline \multirow{3}{*}{1} & (Constant) & .609 & .178 & & 3.425 & .001 \\
\cline { 2 - 7 } & SI & .108 & .036 & .175 & 2.969 & .004 \\
\cline { 2 - 7 } & CI & .150 & .043 & .199 & 3.490 & .001 \\
\cline { 2 - 7 } & PI & .362 & .045 & .474 & 8.057 & .000 \\
\cline { 2 - 6 } & TR & .217 & .045 & .259 & 4.802 & .000 \\
\hline
\end{tabular}

Note: *Dependent Variable: $Y$

Source: Own creation.

Based on Table 3, it is known that the multiple linear regression model is as follows:

$$
\mathrm{Y}=0.609+0.108 \mathrm{SI}+0.150 \mathrm{CI}+0.362 \mathrm{PI}+0.712 \mathrm{TR} \text {. }
$$

The results of the analysis show that for hypothesis $\mathrm{H} 1, \mathrm{H} 2, \mathrm{H} 3$, and $\mathrm{H} 4$ partially have a significant effect on supply chain performance, which is supported by the t test results with a significance value $<0.05$. The Simultaneous Testing (F- Test) is shown in Table 4.

Table 4. Regression Results for Supplier Integration, Customer Integration, Process Integration, and Trust

\begin{tabular}{|l|l|r|r|r|r|c|}
\hline \multicolumn{2}{|l|}{ Model } & $\begin{array}{c}\text { Sum of } \\
\text { Squares }\end{array}$ & df & $\begin{array}{c}\text { Mean } \\
\text { Square }\end{array}$ & F & Sig. \\
\hline \multirow{2}{*}{1} & Regression & 24.751 & 4 & 6.188 & 86.841 & $.000^{\mathrm{b}}$ \\
\cline { 2 - 7 } & Residual & 9.976 & 140 & .071 & & \\
\cline { 2 - 7 } & Total & 34.727 & 144 & & & \\
\hline
\end{tabular}

Note: * Dependent Variable: SCP, ** Predictors: (Constant), TR, CI, PI, SI

Source: Own creation. 
To test and determine the effect simultaneously, and based on Table 4, for hypothesis H5 simultaneously have a significant effect on supply chain performance, where the results show that the significance value is $<0.05$, so that the simultaneous results are significant. The Coefficient of Determination $\left(\mathrm{R}^{2}\right)$ is shown in Table 5.

Table 5. The Coefficient of Determination $\left(R^{2}\right)$

\begin{tabular}{|c|c|r|r|r|}
\hline Model & $\mathrm{R}$ & $\begin{array}{c}\mathrm{R} \\
\text { Square }\end{array}$ & $\begin{array}{c}\text { Adjusted } \\
\text { R Square }\end{array}$ & $\begin{array}{c}\text { Std. Error of the } \\
\text { Estimate }\end{array}$ \\
\hline & $.844^{\mathrm{a}}$ & .713 & .705 & .26693 \\
\hline
\end{tabular}

Note: *Predictors: (Constant), TR, CI, PI, SI, ** Dependent Variable: SCP Source: Own creation.

From Table 5, it can be seen that the coefficient of multiple determination (R square) is 0.713 or $71.30 \%$. This means that the percentage of the magnitude of the influence between supplier integration (SI), customer integration (CI), process integration (PI), and trust (TR) on supply chain performance (SCP) is $71.30 \%$ while the rest is $28.7 \%$ is influenced by other variables not studied.

\subsection{Classic Assumption Test}

\section{Normality (NPar Tests) One-Sample Kolmogorov-Smirnov Test and Multicollinearity test}

Based on Table 6, it can be seen that the Kolmogorov-Smirnov Z value is 0.072 with a significance level of 0.65 , which means it shows that the research variables are normally distributed because the significance level $>0.05$.

Table 6. Normality Test Result

\begin{tabular}{|l|l|r|}
\hline \multicolumn{2}{|c|}{} & \multicolumn{2}{|c|}{$\begin{array}{c}\text { Unstandardized } \\
\text { Residual }\end{array}$} \\
\hline $\mathrm{N}$ & Mean & 145 \\
\cline { 2 - 3 } & Std. Deviation & .0000000 \\
\hline \multirow{2}{*}{ Mormal Parameter's } & .26320093 \\
& Absolute & .072 \\
\cline { 2 - 3 } & Positive & .072 \\
\cline { 2 - 3 } & Negative & .050 \\
\hline Test Statistic & .072 \\
\hline Asymp. Sig. (2-tailed) & & $.065^{\mathrm{c}}$ \\
\hline
\end{tabular}

Note: *Test distribution is Normal, **Test distribution is Normal, ***Lilliefors Significance Correction.

Source: Own creation.

The multicollinearity test is shown in Table 7. 
Table 7. Multicollinearity Test Results.

\begin{tabular}{|c|c|c|c|c|c|c|c|c|}
\hline \multirow{2}{*}{\multicolumn{2}{|c|}{ Model }} & \multicolumn{2}{|c|}{$\begin{array}{c}\text { Unstandardized } \\
\text { Coefficients }\end{array}$} & \multirow{2}{*}{\begin{tabular}{|c|}
$\begin{array}{c}\text { Standardized } \\
\text { Coefficients }\end{array}$ \\
Beta \\
\end{tabular}} & \multirow[b]{2}{*}{$\mathrm{t}$} & \multirow[b]{2}{*}{ Sig. } & \multicolumn{2}{|c|}{$\begin{array}{c}\text { Collinearity } \\
\text { Statistics }\end{array}$} \\
\hline & & B & $\begin{array}{l}\text { Std. } \\
\text { Error }\end{array}$ & & & & Tolerance & VIF \\
\hline 4 & $($ Constant $)$ & .609 & .178 & & 3.425 & .001 & & \\
\hline & SI & .108 & .036 & .175 & 2.969 & .004 & .590 & 1.696 \\
\hline & $\mathrm{CI}$ & .150 & .043 & .199 & 3.490 & .001 & .631 & 1.584 \\
\hline & PI & .362 & .045 & .474 & 8.057 & .000 & .593 & 1.686 \\
\hline & TR & ,217 & ,045 & ,259 & 4,802 & ,000 & ,705 & 1,419 \\
\hline
\end{tabular}

Note: * Dependent Variable: SCP

Source: Own creation.

Based on Table 7, all existing independent variables are known to have a tolerance value greater than 0.1 and VIF less than 10, so this study is free from multicollinearity, and if the results are free from multicollinearity, then this assumption is fulfilled.

\section{Conclusions}

This study's independent variables are supplier integration, customer integration, process integration, and trust, significantly impacting supply chain performance. If sorted, the independent variables that have an influence on the dependent variable from the highest to the lowest are trusted (0.712), process integration (0.362), customer integration (0.150), and supplier integration (0.108). Supply chain performance can be optimized by improving the relationship between the company and its business partners.

Trust can influence supply chain management with trust between parties involved in the supply chain, including companies, suppliers, and distributors. Furthermore, process integration can improve supply chain performance by integrating the company's internal and external processes. Process integration must be carried out internally, namely in production and external companies, concerning supplier integration and customer integration or distributor.

Suggestions that can be given are based on research for the retail sector in Indonesia, so outlets, wherever located, must maintain their trustworthiness. The trust factor's accretion has the highest value, indicating that consumers are very responsive to Indomaret outlets. Furthermore, the company must integrate the internal processes and continue by integrating with external companies, namely supplier integration and customer integration or distributor. Therefore, PT. Indomarco Prismatama also has to trust its existing business partners so that Indomaret outlets will increase in number.

\section{References:}


Alfalla-Luque, R., Medina-Lopez, C., Schrage, H. 2013. A study of supply chain integration in the aeronautics sector. Production Planning \& Control, 24 (8/9), 769-784.

Almeida, M.M.K., Marins, F.A.S., Salgado, A.M.P., Santos, F.C.A., Silva, S.L. 2017. The importance of trust and collaboration between companies to mitigate the bullwhip effect in supply chain management, Maringá, 39(2), 201-210.

AlSagheer, A., Ahli, M. 2011. Impact of supply chain integration on business performance and its challenges. The International Business \& Economics Research Journal (Online), 10(12), 79-92.

Ariani, D., Dwiyanto, B.M. 2013. Analisis pengaruh supply chain management terhadap kinerja perusahaan (Studi Pada Industri Kecil dan Menengah Olahan Khas Padang Sumatera Barat. Jurnal Studi Manajemen dan Organisasi, 10(2), 132141.

Attia, A. 2015. Testing the effect of marketing strategy alignment and triple-A supply chain on performance in Egypt. EuroMed Journal of Business, 10(2), 163-180.

Bagher, A.N. 2018. The effect of supply chain capabilities on performance of food companies. Fin Mark, 2(4), 1-9.

Basu, G., Jeyasingam, J., Habib, M., Letchmana, U., Ravindran, R. 2017. The Impact of Supply Chain Management Practices on the Performance of Private Universities in Malaysia. International Journal of Supply Chain Management, 6(3), 22-35.

Boutayeba, F. 2017. Estimating the returns to education in Algeria. Asian Journal of Economic Modelling, 5(2), 147-153.

Bowersox, D.J. 2013. Supply chain logistics management. 4th ed. New York: McGraw Hill Higher Education, New York, NY.

Bunduchi, R. 2013. Trust, partner selection and innovation outcome in collaborative new product development. Production Planning \& Control, 24 (2/3), 145-57.

Cao, Q., Baker, J., Schniederjans, D. 2014. Bullwhip effect reduction and improved business performance through guanxi: an empirical study. International Journal Production Economics, 158(C), 217-230.

Chavez, R., Yu, W., Gimenez, C., Fynes, B., Wiengarten, F. 2015. Customer integration and operational performance: The mediating role of information quality. Decision Support Systems, 80, 83-95.

Delbufalo, E. 2012. Outcomes of inter-organizational trust in supply chain relationships: A systematic literature review and a meta-analysis of the empirical evidence. Supply Chain Management, 17(4), 377-402.

Deshpande, A.R. 2012. Supply chain management dimensions, supply chain performance and organizational performance: An integrated framework. International Journal of Business and Management, 7(8), 2-19.

Dominguez, R., Cannella, S., Framinan, J. 2014. On bullwhip-limiting strategies in divergent supply chain networks. Computers \& Industrial Engineering, 73(1), 85-95.

Flynn, B.B., Huo, B., Zhao, X. 2010. The impact of supply chain integration on performance: a contingency and configuration approach. Journal of Operations Management, 28(1), 58-71.

Ghozali. 2018. Aplikasi analisis multivariate dengan program IBM SPSS 25. Semarang: Badan Penerbit Universitas Diponegoro.

Goeltz, D.R. 2014. Globalization and hypercompetition-Drivers, linkages, and industry differences. Journal of International Business and Cultural Studies, 8, 1-15.

Hassan, A.A.B.M., Zaharudin, A.B., Yunus, A.B.M. 2015. Delays in physical distribution: a case study of sony supply chain solutions Malaysia. In: The Proceedings of the 4th 
International Seminar on Entrepreneurship and Business (ISEB), 658-674.

He, Y, Lai, K.K., Sun, H., Chen, Y. 2014. The impact of supplier integration on customer integration and new product performance: The mediating role of manufacturing flexibility under trust theory, International Journal of Production Economics, 147, 260-270.

Huang, M.C., Yen, G.F., Liu, T.C. 2014. Reexamining supply chain integration and the supplier's performance relationships under uncertainty. Supply Chain Management: An International Journal, 19(1), 64-78.

Hugos, M.H. 2011. Essentials of supply chain management, $3^{\text {rd }}$ Ed, 332. John Wiley \& Sons. Huo, B. 2012. The impact of supply chain integration on company performance: an organizational capability perspective. Supply Chain Management: An International Journal, 17(6), 596-610.

Huo, B., Qi, Y., Wang, Z., Zhao, X. 2014. The impact of supply chain integration on firm performance: The moderating role of competitive strategy. Supply Chain Management: An International Journal, 19(4), 369-384.

Kumar, V., Rajan, B., Gupta, S., Pazza, I.D. 2019. Customer engagement in service. Journal of the Academy of Marketing Science, 47, 138-160.

Lai, F., Zhang, M., Lee, D.M.S., Zhao, X. 2012. The impact of supply chain integration on mass customization capability: An extended resource-based view. IEEE Transactions on Engineering Management, 59(3), 443-456.

Lamb, C.W., Hair, J.F., McDaniel, C. 2011. Marketing. mason: Cengage learning.

Lau, A.K.W., Tang, E., Yam, R.C.M. 2010. Effects of supplier and customer integration on product innovation and performance: empirical evidence in Hong Kong manufacturers. Journal of Product Innovation Management, 27(5), 761-777.

Linic, S., Christopher, P., Ingram, D.B. 2011. Plasmonic-metal nanostructures for efficient conversion of solar to chemical energy. Nature Materials, 10(12), 911 -921.

Lotfi, Z., Sahran, S., Mukhtar, M. 2013. A product quality-supply chain integration framework. Journal of Applied Sciences, 13, 36-48.

Majid, A.M.F., Dwiyanto, B.M. 2017. Pengaruh long term relationship, information sharing, trust, dan process integration, terhadap kinerja supply chain management. Diponegoro Journal of Management, 6(4), 1-12.

Mellat-Parast, M., Spillan, J.E. 2014. Logistics and supply chain process integration as a source of competitive advantage. The International Journal of Logistics Management, 25(2), 289-314.

Mols, N.P., Hansens, J.R., Villadsen, A.R. 2012. Plural governance: the effect of internal production on supplier performance. Industrial Marketing Management, 41, 874885.

Moyano-Fuentes, J.M., Sacristán-Díaz, J.M., Garrido-Vega, P. 2016. Improving supply chain responsiveness through Advanced Manufacturing Technology: The mediating role of internal and external integration. Production Planning \& Control, 27(9), 686-697.

Munch, O. 2015. First-time-right procurement. Germany: Springer Gabler.

Nagashima, M., Wehrle, F.T., Kerbache, L., Lassagne, M. 2015. Impacts of adaptive collaboration on demand forecasting accuracy of different product categories throughout the product life cycle. Supply Chain Management: An International Journal, 20(4), 415-433.

Nold III, H.A. 2012. Linking knowledge processes with firm performance: Organizational culture. Journal of Intellectual Capital, 13(1), 16-38.

Palomero, S., Chalmeta, R. 2014. A guide for supply chain integration in SMEs. Production 
Planning and Control, 25(5), 372-400.

Sambasivan, M., Siew-Phaik, L., Mohamed, Z.A., Leong, Y.C. 2011. Impact of interdependence between supply chain partners on strategic alliance outcomes: Role of relational capital as a mediating construct. Management Decision, 49(4), 548-569.

Sari, K. 2015. Investigating the value of reducing errors in inventory information from a supply chain perspective. Kybernetes, 44(2), 176-185.

Schoenherr, T., Swink, M. 2012. Revisiting the arcs of integration: Cross- validations and extensions. Journal of Operations Management, 30(1/2), 9-115.

Seebacher, G., Winkler, H. 2015. A capability approach to evaluate supply chain flexibility. International Journal of Production Economics, 167, 177-186.

Sezhiyan, D.M., Page, T., Iskanius, P. 2011.The impact of supply effort management, logistics capability, and supply chain management strategies on firm performance. International Journal of Electronic Transport, 1(1), 26-44.

Shahbaz, M.S., Rasi, R.Z., Zulfakar, M.H., Bin, M.D.F., Abbas, Z., Mubarak, M.F. 2018. A novel metric of measuring performance for supply chain risk management: Drawbacks and qualities of good performance. Journal of Fundamental and Applied Sciences, 10(3S), 967-988.

Srinita. 2018. Sustainable supply chain management in the quantitative framework Developments, directions, and economic analysis in Indonesia. International Journal of Supply Chain Management, 7(5), 409-417.

Sugiyono. 2017. Metode penelitian kuantitatif, kualitatif, dan R\&D. Bandung: Alfabeta, CV.

Wong, C.Y., Boonitt, S., Wong, C.W.Y. 2011. The contingency effects of environ- mental uncertainty on the relationship between supply chain integration and operational performance. Journal of Operations Management, 29(6), 604-615.

Wu, L., Chuang, C.H., Hsu, C.H. 2014. Information sharing and collaborative behaviors in enabling supply chain performance: A social exchange perspective. International Journal of Production Economics, 148, 122-132.

Xiao, Y., Zheng, X., Pan, W., Xie, X. 2010. Trust, relationship commitment and cooperative performance: supply chain management. Chinese Management Studies, 4(3), 231-243.

Yu, W. 2015. The effect of IT-enabled supply chain integration on performance. Production Planning \& Control, 26(12), 945-57.

Zainurossalamia, S., Hidayat, T. 2020. Supply chain agility, supplier synergy, cooperative norms, and competitive advantage: Mediating role of supplier performance. International Journal of Supply Chain Management, 9(4), 301-309.

Zhang, M., Lettice, F., Chan, H.K., Nguyen, H.T. 2018. Supplier integration and firm performance: The moderating effects of internal integration and trust. Production Planning and Control, 29(10), 802-813.

Zhao, L., Huo, B., Sun, L., Zhao, X. 2013. The impact of supply chain risk on supply chain integration and company performance: A global investigation. Supply Chain Management. An International Journal, 18(2), 115-131.

Zhao, L., Huo, B., Sun, L., Zhao, X. 2013. The impact of supply chain risk on supply chain integration and company performance: a global investigation. Supply Chain Management: An International Journal, 18(2),115-131. 